\title{
PERANAN AUDIT OPERASIONAL DALAM MENINGKATKAN EFEKTIVITAS PENJUALAN PADA PT. DELTA INTERNUSA KOTA PALOPO
}

\author{
ERWIN AHMAD, IKBAL, I KETUT PATRA
}

\begin{abstract}
ABSTRAK
Audit operasional sebagai bagian dari fungsi pengendalian merupakan suatu alat bagi manajemen untuk mengukur dan mengevaluasi kegiatan yang telah dilaksanakan. Manajemen harus memperhatikan segala aspek dalam perusahaan terutama unsur-unsur yang dapat mempengaruhi penetapan laba rugi perusahaan adalah penjualan, karena dengan adanya kegiatan penjualan memungkinkan terciptanya pendapatan yang selanjutnya setelah dikurangi dengan berbagai biaya operasi akan menciptakan laba yang dalam jangka panjang berguna untuk menjamin continuitas perusahaan atau rugi yang dalam jangka waktu tertentu dapat membuat perusahaan tidak dapat lagi melanjutkan usahanya.

Tujuan dari audit operasional itu sendiri adalah untuk memberikan penilaian terhadap efisiensi dan efektivitas serta keekonomisan dari suatu bagian operasional perusahaan yang merupakan akibat yang diharapkan dari sistem pengendalian intern yang baik. Penelitian ini dilaksanakan di PT. Delta Internusa Kota Palopo, dengan populasi dan sampel sebanyak 21 orang. Variabel indenpenden dalam penelitian ini adalah peranan audit operasional. Untuk variabel dependen dalam penelitian ini adalah efektivitas penjualan. Data dalam penelitian ini merupakan data primer yang diperoleh dari penyebaran kuesioner secara langsung kepada seluruh karyawan PT. Delta Internusa Kota Palopo. Analisis yang digunakan untuk menguji hipotesis pada penelitian ini adalah analisi deskriftif dan analisi statistik.

Hasil penelitian ini menunjukkna bahwa audit operasional berperan dalam meningkatkan efektivitas penjualan pada PT. Delta Internusa Kota Palopo, esuai dengan hasil penelitian yang dilakukan oleh penulis, menunjukkan bahwa efektivitas penjualan dari segi target dan realisasi penjualan yang dianggarkan perusahaan mampu memenuhi target yang telah ditetapkan tiap tahunnya oleh perusahaan.

Kesimpulan dari hasil penelitian ini adalah penjualan untuk tahun 2010 dan 2011 telah dilaksanakan dengan efektif oleh PT. Delta Internusa Kota Palopo, hal ini dapat dilihat dari data penjualan yang berhasil penulis kumpulkan selama dua periode yaitu pada tahun 2010 dan 2011. Dari data penjualan tahun 2010 dan 2011 dapat disimpulkan bahwa tercapainya target penjualan baik dari jumlah hal maupun nilai dalam rupiah.

Kata Kunci : Audit Operasional dan Efektivitas Penjualan
\end{abstract}




\section{Pendahuluan}

\section{Latar Belakang}

Semakin berkembangnya parusahaan tentunya di ikuti dengan semakin beragam dan luasnya aktivitas serta permasalahan yang di hadapi sehingga mendorong suatu bidang baru dari auditing yaitu pemeriksaan operasional (audit operasional) pemeriksaan operasional merupakan akativitas suatu organisasi yang bertujuan untuk memeriksa evfisiensi dan efektivitas suatu perusahaan. Aktivitas pemeriksaan operasional akan bermanfaat banyak bagi perusahaan karena dapat menunjang kelancaran dari pelaksanaan operasi perusahaan terhadap kontinuitas perusahaan di masa yang akan datang.

Keberhasilan suatu perusahaan dalam mendapatkan keuntungan yang maksimal tidak terlepas dari adanya pengendalian efektif atas semua kegiatan yang ada dalam perusahaan, sebab itu perusahaan harus berusaha untuk menghidari adanya pemborosan dalam hal - hal yang dapat membawa kerugian bagi perusahaan.

Audit operasional sebagai bagian dari fungsi pengendalian merupakan suatua alat bagi manajemen utuk mengukur dan mengepaluasi kegiatan yang telah di laksanakan. Manajemen harus memperhatikan segalah aspek dalam perusahaan terutama unsur - unsur yang dapat mempengaruhi penetapan labarugi perusahaan adalah penjualan, karena dengan adanya kegiatan penjulan memungkinkan terciptanya pendapatan yang selanjutnya setelah dikurangi dengan berbagai biaya operasi akan menciptakan laba yang dalam jangka panjang berguna untuk menjamin kontinuitas perusahaan atau rugi yang dalam jagnka waktu tertentu dapat membuat perusahaan tidak dapat lagi melanjutkan usahanya.

Tujuan dari audit operasional itu sendiri adalan untuk memberikan penilaian terhadap efisiensi dan efektivitas peusahaan serta keekonomisan dari suatu bagian operasional yang merupakan akibat yang diharapkan dari sistem pengendalian intern yang baik.

Berdasarkan uraiaan tersebut diatas maka penulis tertarik untuk melakukan penelitian dengan judul : "Peranan Audit Operasional Dalam Meningkatkan Efektivitas Penjualan Pada PT. Delta Internusa Kota Palopo"

Masalah penelitian ini adalah bagaimana peranan audit operasional atas pejualan dalam meningkatkan efektivitas penjualan pada PT. Delta Internusa kota palopo?. Tujuan penelitian ini adalah untuk menetahui bagaimana peranan audit operasional atas pejualan dalam meningkatkan efektivitas penjualan pada PT. Delta Internusa kota palopo. 


\section{Metode Penelitian}

Tempat dan Waktu Penelitian

Untuk memperoleh data yang dibutuhkan dalam penelitan ini, penulis mengadakan penelitian pada PT. Delta Internusa kota palopo, yang beralamatkan di jalan patang 1 No. 4 kota palopo. Adapun waktu penelitian kurang lebih 2 bulan. Jenis dan sumber data

1. Data primer

2. Data sekunder

Populasi dan sampel

Dalam pemelitan ini populasi sekaligus dijadikan sampel yang akan diteliti yaitu karyawan perusahaan PT. Delta Internusa kota palopo sebanyak 21 orang.

Metode pengumpulan data

Metode pengumpulan data yang digunakan dalam penelitian ini adalah: (a) Penelitian lapangan; Penelitian lapangan yaitu suatu penelitian yang dilakukan secara langsung pada perusahaan yang menjadi lokasi penelitian untuk memperoleh data primer, (b) Studi kepustakaan; Penelitian ini dimaksudkan untuk memperoleh data sekunder, yaitu penelitian yang dilakukan melalui pengumpulan data dengan membaca sumber - sumber, menganalisis dan menarik suatu kesimpulan melalui buku - buku yang menjadi buku wajib dalam mata kulia yang ada hubungannya dengan penelitian ini. Penelitian ini akan menjadi landasan teoritis pagi pelaksanaan analisis yang akan dilakukan.

Metode Analisis data

Metode analisis data yang digunakan dalam penelitian ini adalah: (a) Metode deskriftif; Penelitian deskriftif merupakan yang berusaha yang mendiskripsikan dan menginterprestasikan sesuatu, misalnya kondisi atau hubungan yang ada, pendapat yang berkembang, proses yang sedang berlangsung, efek atau akibat yang terjadi, atau tentang kecenderungan yang tengah berlangsung. Penulis melakukan analisis mengenai informasi-informasi dan data yang berhasil diperoleh baik yang dilakukan dengan kuisioner, wawancara, maupun observasi. Hipotesis yang digunakan dalam skiripsi ini adalah diduga bahwa audit operasional mampu meningkatkan efektivitas penjualan serta target penjualan dapat tercapai, (b) Analisis statistik; Pengajuan data hipotesis merupakan suatu cara dalam statistik untuk menguji anggapan dasar yang masih bersifat sementara sehingga dapat ditarik kesimpulan statisti mengenai diterima atau ditolaknya hipotesis. Langkah-langkah yang ditempuh dalam analisis statisti adalah sebagai berikut :

a. Memisahkan setiap jawaban responden sesuai dengan jawaban yang diberikan yaitu ya $(\mathrm{Y})$, ragu-ragu $(\mathrm{R})$ dan tidak $(\mathrm{T})$.

b. Menjumlahkan total jawaban ya $(\mathrm{Y})$, ragu-ragu $(\mathrm{R})$ dan tidak $(\mathrm{T})$. 
c. Membandingkan jumlah jawaban ya (Y) dengan jawaban kuesioner.

d. Membuat persentase perhitungan dengan cara :

Untuk menghitung nilai persentase hasil jawaban para responden menggunakan perhitungan

$$
\frac{\text { ¿jawaban"Ya }}{\text { Sjawaban kuesioner }}
$$

e. Membuat kesimpulan

Untuk keperluan interprestasi hasil perhitungan presentase penulis akan menggunakan ketentuan yang di kemukakan oleh dean J. Chempion (1990) dalam Antonius Effendi (2004) yang menyebabkan klasifikasi sebagai berikut:

1. $0 \%-25 \%$ berarti audit opersional fungsi penjualan tidak berperan dalam menunjang penjualan yang efektif

2. $26 \%-50 \%$ berarti audit oprasional fungsi penjulan sedikit berperan dalam menunjang penjualan yang efektif

3. $51 \%-75 \%$ berarti audit oprasional fungsi penjulan berperan dalam menunjang penjualan yang efektif

4. $76 \%-100 \%$ berarti audit oprasional fungsi penjulan sangat berperan dalam menunjang penjualan yang efektif

Validitas Dan Reliabilitas Instrumen

Validitas

Uji validitas dalam penelitian ini menggunakan analisis faktor (factor analysis) sebuah faktor dikatakanvalid apabila memiliki factor loading berada pada kisaran 0,40 ke atas.

Reliabilitas

Tekhnik statistik yang digunakan untuk pengujian tersebut dengan koefisien cronbach's alpha merupakan uji reliabilitas untuk alternatif jawaban lebih dari dua. Menurut Supramono dan Utami (2004) secara umum suatu instrumen dikatakan reliabel jika memiliki koefisien cronbach's alpha $>0,6$.

\section{Hasil Penelitian Dan Pembahasan}

\section{Analisis Target Penjualan dan Realisasi Penjualan}

Analisis prestasi penjualan di lakukan untuk mengetahui prestasi penjualan PT. Delta Internusa Kota Palopo, sehingga dapat di tentukan apakah aktivitas penjualan telah berjalan efektif. Dari hasil wawancara dan penyebaran kuesioner yang dilakukan penulis untuk menilai efektivitas penjualan dari segi target dan realisasi penjualan yang dianggarkan perusahaan, dapat disimpulkan bahwa perusahaan mampu memenuhi target yang telah ditetapkan setiap tahunnya dan selisih yang ada masih dalam batas toleransi. Untuk selisi pencapaian realisasi 
penjualan, perusahaan membut kebijakan bahwa jika selisih (kurang) antara 3\% sampai dengan 5\% dari target yang telah ditetapkan periode yang bersangkutan maka penjualan tersebut sudah memenuhi target penjualan.

Untuk mengetahui tingkat efektivitas penjualan perusahaan, penulis menggunakan data yang diambil dari bagian penjualan PT. Delta Internusa Kota Palopo selama dua periode yaitu penjualan tahun 2010 dan 2011 yang akan dianalisis dengan menggunakan teknik analisis varians apakah penjualan telah sesuai dengan target penjualan yang telah ditetapkan. Persentase varians yang terjadi dihitung dengan membandingkan penjualan aktual dengan anggaran penjualan pada tahun yang bersangkutan. Target penjualan tahun 2010 dan 2011 dapat dilihat pada tabel 4.1 dan tabel 4.2.

TABEL 4.1.

TARGET DAN REALISASI PENJUALAN

PT. DELTA INTERNUSA KOTA PALOPO TAHUN 2010

\begin{tabular}{|l|l|l|l|l|l|l|}
\hline \multirow{2}{*}{$\begin{array}{l}\text { Jenis } \\
\text { Produksi }\end{array}$} & Target & Dos/Bal & Rupiah & Dos/Bal & Rupiah & Dolisih \\
\hline Clas Mild 16 & 2.640 & 2.692 .800 .000 & 2.880 & 2.937 .600 .000 & 240 & 244.800 .000 \\
\hline $\begin{array}{l}\text { Clas Mild } \\
\text { Menthol 16 }\end{array}$ & 144 & 146.880 .000 & 146 & 148.920 .000 & 2 & 2.040 .000 \\
\hline Clas Mild 12 & 192 & 143.040 .000 & 198 & 147.510 .000 & 6 & 4.524 .000 \\
\hline Nikki Super & 480 & 379.200 .000 & 624 & 492.960 .000 & 144 & 113.760 .000 \\
\hline Jumlah & 3.456 & 3.361 .920 .000 & 3.848 & 3.726 .990 .000 & 392 & 365.070 .000 \\
\hline
\end{tabular}

Sumber : Bagian keuangan PT. Delta Internusa Kota Palopo yang telah diolah.

Berdasarkan tabel 4.1 dapat diketahui bahwa total penjualan tahun 2010 adalah 3.848 bal senilai Rp 3.726 .990 .000 sedangkan total penjualan yang ditargetkan adalah 3.456 bal senilai Rp 3.361.920.000 sehingga dapat disimpulkan bahwa target penjualan untuk tahun 2010 tercapai.

TABEL 4.2.

TARGET DAN REALISASI PENJUALAN

PT. DELTA INTERNUSA KOTA PALOPO TAHUN 2011

\begin{tabular}{|l|l|l|l|l|l|l|}
\hline \multirow{2}{*}{$\begin{array}{l}\text { Jenis } \\
\text { Produksi }\end{array}$} & \multicolumn{4}{|l|}{ Target } & Ros/isasi & Selisih \\
\hline Clas Mild 16 & 3.120 & 3.182 .400 .000 & 3.696 & 3.769 .920 .000 & 576 & 587.520 .000 \\
\hline $\begin{array}{l}\text { Clas Mild } \\
\text { Menthol 16 }\end{array}$ & 144 & 146.880 .000 & 144 & 146.880 .000 & 0 & 0 \\
\hline Clas Mild 12 & 240 & 178.800 .000 & 240 & 178.800 .000 & 0 & 0 \\
\hline Nikki Super & 576 & 455.040 .000 & 672 & 530.880 .000 & 96 & 75.840 .000 \\
\hline Jumlah & 4.080 & 3.963 .120 .000 & 4.752 & 4.626 .480 .000 & 672 & 663.360 .000 \\
\hline
\end{tabular}

Sumber : Bagian keuangan PT. Delta Internusa Kota Palopo yang telah diolah.

Berdasarkan tabel 4.2 dapat diketahui bahwa total penjualan tahun 2011 adalah 4.752 bal senilai $\mathrm{Rp} 4.626 .480 .000$ sedangkan total penjualan yang ditargetkan adalah 4.080 bal senilai Rp 3.963.120.000 sehingga dapat disimpulkan bahwa target penjualan untuk tahun 2010 tercapai. 


\section{Analisis Biaya Penjualan}

Besarnya biaya penjualan yang terjadi juga mempengaruhi besarnya tingkat efektivitas penjualan dalam menganalisi penjualan yang terjadi. Biaya penjualan yang telah dikeluarkan oleh PT. Delta Internusa Kota Palopo meliputi biaya transportasi, biaya pengiriman, dan biaya asuransi.

Perusahaan mempunyai kebijakan bahwa jika selisih realisasi biaya penjualan tidak melebihi 3\% dari anggaran biaya penjualan yang telah ditetapkan untuk periode yang telah bersangkutan maka selish biayapenjualan tersebut masih dapat ditoleransi.

Berikut ini anggaran dan biaya penjualan PT. Delta Internusa Kota Palopo tahun 2010 dan 2011.

\section{TABEL 4.3}

TARGET DAN REALISASI PENJUALAN

PT. DELTA INTERNUSA KOTA PALOPO TAHUN 2010 DAN 2011

\begin{tabular}{|l|l|l|l|}
\hline Tahun & Target & Realisasi & Selisih \\
\hline 2010 & $\operatorname{Rp~437.400.000~}$ & $\operatorname{Rp~427.150.000~}$ & $\operatorname{Rp~10.250.000~}$ \\
\hline 2011 & $\operatorname{Rp~438.000.000~}$ & $\operatorname{Rp~422.700.000~}$ & $\operatorname{Rp~5.300.000~}$ \\
\hline
\end{tabular}

Sumber : Bagian keuangan PT. Delta Internusa Kota Palopo yang telah diolah.

Dari tabel 4.3 dapat dilihat realisasi penjualan tahun 2010 yang terjadi adalah Rp 427.150.000 dan tahun 2011 adalah Rp 422.700.000, sedangkan target penjualan yang ditetapkan oleh perusahaan tahun 2010 adalah Rp 437.400.000 dan tahun 2011 adalah Rp 438.000.000. hal ini menunjukkan bahwa realisasi penjualan PT. Delta Internusa Kota Palopo dibawah target penjualan yang telah ditentukan.

\section{Pengujian Metode Analisis}

Analisis Deskriftif

Metode ini dirumuskan untuk mengetahui berperannya audit operasional dalam meningkatkan efektivitas pejualan PT. Delta Internusa Kota Palopo. Penulis melakukan penelitian terhadap perusahaan dan penyebaran kuesioner berisikan pertanyaan yang berhubungan dengan masalah yang dibahas. Sesuai dengan hasil penelitian terhadap perusahaan dan penyebaran kuesioner kepada responden, maka penulis dapat menyimpulkan bahwa audit operasional berperan dalam menunjang efektivitas penjualan pada PT. Delta Internusa Kota Palopo.

Analisis Statistik

Analisis statistik merupakan suatu analisis dalam mengukur indikator peranan audit operasional dalam meningkatkan efektivitas penjualan. Analisis ini dilakukan dengan penyebaran kuesioner kepada para responden untuk mengukur berperan tidaknya audit opersional fungsi penjualan dalam menunjang efektivitas penjualan.

Langkah-langkah yang harus dilakukan dalam pengolahan kuesioner adalah sebagai berikut :

1. Memisahkan tiap-tiap jawaban responden sesuai dengan jawaban yang diberikan yaitu : Ya, Ragu-ragu, dan Tidak. 
2. Menjumlahkan berapa banyak jawaban Ya, Ragu-ragu, dan Tidak.

3. Membandingkan antara jawaban Ya dengan jumlah jawaban kuesioner.

4. Menghitung persentase.

\section{Penutup}

Kesimpulan dala penelitian ini adalah: (a) Penjualan untuk tahun 2010 dan 2011 telah dilaksanakan dengan efektif oleh PT. Delta Internusa Kota Palopo, hal ini dapat dari data penjualan yang berhasil penulis kumpulkan selama dua periode yaitu pada tahun 2010 dan 2011. Dari data penjualan PT. Delta Internusa Kota Palopo untuk tahun2010 dan 2011 dapat disimpulkan bahwa target penjualan pada tahun 2010 dan 2011 tercapai, baik dari jumlah hal maupun nilai dalam rupiah, (b) Sesuai dengaan hasil perhitungan penyebaran kuesioner yang dilakukan oleh penulis dapat dilhat bahwa audit operasional pada PT. Delta Internusa Kota Palopo berperan, begitu pula dengan efektivitas penjualan dapat disimpulkan bahwa kegiatan penjualan pada PT. Delta Internusa Kota Palopo efektif. Dengan demikian sesuai dengan data penjualan dan dari hasil penyebaran kuesioner, maka dapat disimpulkan bahwa audit operasional mampu meningkatkan efektivitas sehingga target penjualan pada PT. Delta Internusa Kota Palopo dapat tercapai.

Adapun harga rokok perbalnya pada PT. Delta Internusa Kota Palopo adalah sebagai berikut :

$$
\begin{array}{lll}
\text { 1. } & \text { Clas Mild 10 } & =\mathrm{Rp} 1.020 .000 \\
\text { 2. } & \text { Clas Mild Menthol 16 } & =\mathrm{Rp} 1.020 .000 \\
\text { 3. } & \text { Clas Mild 12 = Rp } & =\mathrm{Rp} 745.000
\end{array}
$$

Adapun saran dari penelitian ini adalah untuk membantu perusahaan dalam meningkatkan efektivitas penjualan yaitu sebaiknya kebijakan mengenai selisih presentase pencapaian anggaran penjualan sebesar 3\% dituangkan dalam bentuk surat keputusan ssecara tertulis dan bukan merupakann kebijakan lisan.

\section{Daftar Pustaka}

Anonim, 2003, United States General Accounting Office. Generally Accepted Govemment Auditing Standards (GAGAS) 2003 Revision. Washington DC: GAO

ANTHONY, R.N dan V. Govindarajan. 2001. Management Controls Systems.

Antonius effendi (2004), Peranan Audit Operasional, Fakultas Ekonomi Universitas Widyatama. 
Basu Swastha, 2005, Manajemen Penjualan, edisi pertama, cetakan keempar, Penerbit : BPFE, Yogyakarta.

Ely Suhayati, Siti Kurnia Rahayu ; 201, Auditing. Bandung : Graha Ilmu.

Guy, Alan, and Wayne, 2003, Auditing 2, jakarta : Ghalia Indonesia.

Henry Simamora. 2000. Akuntansi Basis Pengambilan Keputusan Bisnis, Jakarta : Salemba Empat.Chairul Marom (2002;28)

Hongren, Charles T, Harrison jr., Walter T., 2007, Akuntansi, Jilid 1, Yogyakarta: UPP AMP YKPN.

La, Midjan, 2001. Sistem Informasi Akuntansi, Bandung : Lingga Jaya.

Mulyadi, Auditing Buku 1, Salemba Empat, jakarta, 2002.

Sekaran, 2003. Reseach Methods for business. A Skill Building Approach, Fourth Edition, New York: John Wiley \& Sons, Inc.

Sukrisno, Agus. 2008. Auditing Pemeriksaan oleh Kantor Akuntan Publik Jilid 1. Jakarta: Lembaga Penerbit Fakultas Ekonomi Universitas Indonesia.

Tunggal Amin Widjaja. 2000. Dasar-dasar Audit Operasional . Jakarta: Harvarindo

Widjayanto, Nugroho. 2004. Pemeriksaan Operasional Perusahaan. Jakarta: FEUI 